\title{
The Relationship of Androgen Receptor Expression with Other Prognostic Factors in Breast Cancer
}

\author{
Meric Emre Bostanci (Corresponding author) \\ Sivas Cumhuriyet University, Faculty of Medicine, \\ Department of Surgical Oncology, Sivas, Turkey \\ E-mail: drmericemrebostanci@gmail.com \\ Onur Avci \\ Sivas Cumhuriyet University, Faculty of Medicine, \\ Department of Anesthesiology and Reanimation, Sivas, Turkey \\ Kursat Karadayi \\ Sivas Cumhuriyet University, Faculty of Medicine, \\ Department of Surgical Oncology, Sivas, Turkey
}

\begin{abstract}
Aim:

Breast cancer is the most common type of cancer in women and it is the second most common cause of mortality in women. In the last 20 years, there has been an increase in the incidence of breast cancer, while mortality has decreased. The androgen receptor (AR) belongs to the same family as other steroid hormone receptor. The androgen receptor (AR) belongs to the same family as other steroid hormone receptors. Therefore, it shows high structural, functional, and topographic similarity to estrogen and progesterone receptors. In this study, we aimed to investigate the relationship between androgen receptor expression and breast cancer prognostic factors.
\end{abstract}

\section{Material and Methods:}

Mastectomy materials belonging to 26 cases examined between 2016-2019 in the Department of Surgical Oncology, Faculty of Medicine, Sivas Cumhuriyet University. Clinical and pathological features such as retrospectively patient age, tumor type, tumor size, lymph node involvement, lymphovascular invasion, pathological stage, tumor grade, Ki-67 index, HER-2 / neu, androgen receptor, estrogen receptor, progesterone receptor were obtained from patient files.

\section{Results}

As a result of statistical analysis, a statistically significant relationship was found between AR expression and lymphovascular invasion of tumors, lymph node involvements, estrogen receptor, progesterone receptor, HER-2 / neu expression, and Ki-67 index. There was no significant difference between AR expression and menopausal status, tumor grade, tumor diameter. A negative correlation was observed between AR expression and pathological stage.

\section{Conclusions:}

As a result, androgen receptor positivity is associated with better clinical outcomes. Its correlation with both estrogen receptor and progesterone receptor positivity suggests that the predictive and prognostic value of this receptor can be increased by assessing the condition of the patient's estrogen receptor and progesterone receptors.

Key words: Androgen receptor, Breast cancer, prognosis

\section{Special Issue of Health Sciences}

DOI: $10.7176 / J S T R / 6-03-34$ 


\section{Meme Kanserinde Androjen Reseptör Ekspresyonunun Diğer Prognostik Faktörler İle İlişkisi}

\section{Özet}

Giriş:

Meme kanseri kadınlarda en sık görülen kanser türüdür ve kadınlardaki mortalitenin en yaygın ikinci sebebidir. Son 20 yılda, meme kanseri insidansında artış ancak mortalitesinde düşüş vardır. Androjen reseptörü (AR) diğer steroid hormon reseptörleriyle aynı aileye aittir ve bu nedenle östrojen ve progesteron reseptörlerine yüksek yapısal, fonksiyonel ve topografik benzerlik gösterir. Bu çalışmada androjen reseptör ekspresyonu ile meme kanserinin prognostik faktörleri arasındaki ilişkiyi araştırmayı amaçladık.

\section{Gereç ve Yöntem:}

Cumhuriyet Üniversitesi Tıp Fakültesi Cerrahi Onkoloji BD'nda 2016-2019 yılları arasında incelenen 26 olguya ait mastektomi materyalleri çalışma grubunu oluşturmuştur. Hasta dosyalarından retrospektif olarak hasta yaşı, tümör tipi, tümör boyutu, lenf nodu tutulumu, lenfovasküler invazyon, patolojik evre, tümör derecesi, Ki-67 indeksi, HER-2/neu, androjen resptörü, östrogen reseptörü, progesteron reseptörü gibi klinik ve patolojik özellikler elde edildi.

\section{Bulgular:}

İstatistiksel analizlerin sonucunda, AR ekspresyonu ile tümörlerin lenfovasküler invazyon ve lenf nodu tutulumları, östrojen reseptörü, progesteron reseptörü ve HER-2/neu ekspresyonu ve Ki-67 indeksi arasında istatistiksel olarak anlamlı bir ilişki mevcuttu. AR ekspresyonu ile menopoz durumu, tümör derecesi, tümör çapı arasında anlamlı farklılık olmadığı gözlendi. AR ekspresyonu ile patolojik evre arasında da negatif korelasyon olduğu görüldü.

\section{Sonuç:}

Sonuç olarak androjen reseptörü pozitifliği daha iyi klinik sonuçlarla ilişkilidir. Hem östrojen reseptörü hem de progesteron reseptörü pozitifliği ile korelasyonu, bu reseptörün prediktif ve prognostik değerinin hastanın östrojen reseptörü ve progesteron reseptörlerinin durumu değerlendirilerek arttrrılabileceğini düşündürmektedir.

Anahtar Kelimeler: Androjen reseptörü, Meme kanseri. prognoz

\section{GİRIŞ ve AMAÇ}

Meme kanseri dünya genelinde kadınlar arasında en yaygın görülen kanserlerden biridir (1). Meme kanseri 30 yaşından önce nadir olup, bu yaşı takip eden reprodüktif yıllarda hızlı bir tırmanış gösterir. $\mathrm{Bu}$ artış menopoz sonrasında da yavaş eğimle yükselmeye devam eder. Kadınlarda kansere bağlı ölümlerin $\% 18$ 'i meme kanseri nedeniyle olmakta ve meme kanserine bağlı ölümler; akciğer ve kolorektal kanserlerden sonra üçüncü sırayı almaktadır (2).

Hastanın hormon reseptör durumunun meme kanseri tanısını, histolojik tiplendirmesini ve tedaviye yanıt değerlendirmesini etkilediği bilinmektedir (3).

Androjen reseptörü (AR) diğer steroid hormon reseptörleriyle aynı aileye aittir ve bu nedenle östrojen ve progesteron reseptörlerine yüksek yapısal, fonksiyonel ve topografik benzerlik gösterir (4).

AR'ü ve diğer tip steroid reseptörleri arasındaki ilişki hormon tedavisinin daha etkili planlanmasına yardımcı olabilir. Kanser hücrelerinde AR ekspresyonunun sıklıkla östrojen reseptörü (ÖR) ve hatta daha sıklıkla progesteron reseptörü (PR) ekspresyonuna eşlik ettiği gösterilmiştir $(5,6)$.

İnsan meme kanserinde AR'nin önemi östrojen negatif meme tümörlerinde hedeflenebileceğinin bulunmasıyla daha da artmıştır (7). AR ekspresyonunun kaybı yüksek nükleer grade ve negatif ÖR, PR ve Her2/neu ekspresyon durumuyla ilişkilidir $(8,9)$. Ancak, meme karsinogenezinde AR ekspresyonunun kaybından sorumlu mekanizmalar hala net değildir (10).

AR primer meme kanserlerinin \%80'inde ekspresedir, bu da ÖR veya PR eksprese edenlerin yüzdesine benzer veya daha yüksektir $(11,12)$. 
Androjen reseptörü ekspresyonu, meme kanseri alt tiplerine göre değişir ve bir hastanın östrojen reseptör durumu ile ilişkili olabilir. Östrojen reseptörü pozitif tümörler için androjen reseptörü ekspresyonu oranlarının \% 84-95 olduğu bildirilmiştir $(13,14)$.

\section{GEREÇ ve YÖNTEM}

Cumhuriyet Üniversitesi Tıp Fakültesi Cerrahi Onkoloji BD’nda 2016-2019 yılları arasında incelenen 26 olguya ait mastektomi materyalleri çalışma grubunu oluşturmuştur. Çalışmaya dahil edilen 26 olgunun 19'u invaziv duktal karsinom, 7'si diğer karsinom tiplerindendir.

Hasta dosyalarından retrospektif olarak hasta yaşı, tümör tipi, tümör boyutu, lenf nodu tutulumu, lenfovasküler invazyon, patolojik evre, tümör derecesi, Ki-67 indeksi, HER-2/neu, androjen resptörü, östrogen reseptörü, progesteron reseptörü gibi klinik ve patolojik özellikler elde edildi. Olgularda 50 yaş ve üzerinde olanlar postmenopozal, 50 yaş altında olanlar premenopozal olarak kabul edildi.

AR ile tümör dokusunda kordaki tüm alanda $\geq \% 10$ nükleer boyanan hücre bulunması pozitif olarak kabul edildi. Olgularda androjen reseptörünün, ÖR, PR ve HER-2/neu ekspresyonu, menopozal durum, grade, tümör boyutu, tümör derecesi, aksiller lenf nodu tutulumu, evre, lenfovasküler invazyon, Ki-67 indeksi gibi klinikopatolojik parametrelerle ilişkisi araştırıldı.

İstatistik çalışmaları Windows için SPSS (Statistical Package for Social Sciences) 22.0 programı kullanılarak yapıldı. Çalışma verilerini değerlendirmek için ki-kare testi ve tanımlayıcı istatistiksel yöntemler kullanıldı. Farklılıkları p $<0.05$ (iki taraflı test) değerinde istatistiksel olarak anlamlı kabul ettik ve sonuçlar \% 95 güven aralığında değerlendirildi.

\section{BULGULAR}

Yirmi altı meme kanseri hastasının verileri analiz edildi ve bu hastaların ortanca yaşı 56 idi (Aralık: 2681 yıl). Menopoz öncesi dönemde 12 hastaya (\% 46.1), menopoz sonrası dönemde 14 hastaya ( $\% 53.8)$ tanı konuldu.

Çalışmaya katılanlarda tanı konulan tümör tipleri 20 hastada (\% 76.9) invaziv duktal karsinom (İDK) ve 6 hastada (\% 23.0) diğer karsinom tipleridir.

Toplam 26 hastadan 5'i (\% 19.2) evre I meme kanseri, 12'si (\% 46.1) evre II, 7'si (\% 26.9) evre III ve 2'si (\% 7.6) evre IV idi. Aksiller lenf nodlar1 10 hastada (\% 38.4) negatif, 16 hastada (\% 61.5) pozitifti.

Altı hastada (\% 23.0) tümör çap1 $5 \mathrm{~cm}$ veya daha büyüktü ve 20 hastada (\% 76.9) 5 cm'den küçüktü. 10 hastada (\% 38.4) lenfovasküler invazyon, 6 hastada (\% 23.0) multisentrisite saptand1.

Östrojen reseptörü pozitifliği 17 hastada (\% 65.3), progesteron reseptör pozitifliği 15 hastada (\%57.6) saptand. HER2 pozitifliği 12 hastada (\% 46.1) mevcuttu. Üç hastada (\% 11.5) triple negatif olarak bulundu. Ki-67 proliferasyon indeksi skoru 10 hastada $(\% 38.4)$ düşük $(\leq \% 15)$ ve 16 hastada $(\% 61.5)$ yüksek $(\%>15)$ idi.

Olguların yaş ve menopoz durumu ile AR ekspresyonu arasındaki ilişkiye bakıldığında menopoz öncesi ve menopoz sonrası olan hasta grupları arasında AR ekspresyonu açısından anlamlı farklılık olmadığı gözlendi $(p=0.225)$

Tümörlerin lenfovasküler invazyon ve lenf nodu tutulumları ile AR ekspresyon durumları karşılaştırıldı. AR pozitif olan 13 olgunun 2 tanesinde lenfovasküler invazyon ve beş tanesinde aksiller lenf nodu tutulumu saptand1, ancak AR negatif olan 13 olgunun da yine 11 tanesinde lenfovasküler invazyon ve 2 tanesinde de aksiller lenf nodu tutulumu görüldü. Bu parametreler ile $\mathrm{AR}$ ekspresyonu arasında istatistiksel olarak anlamlı bir ilişki bulundu (sırasıyla $\mathrm{p}=0.016$ ve $\mathrm{p}=0.006$ ).

Tümör dereceleri ile AR ekspresyon durumu karşılaştırıldı. Derece 1 ile uyumlu olan 8 olgunun 6 tanesinde (\%75.0) AR pozitif, derece 2 ile uyumlu 12 olgunun ise 5 tanesinde (\%41.6) AR pozitif, Derece 3 ile uyumlu olan 6 olgunun 1 tanesinde (\%16.6) AR pozitif bulundu. Bu sonuca göre AR ekspresyonunun tümör derecesi ile arasındaki ilişki istatistiksel olarak anlamlı değildi ( $\mathrm{p}=0.087)$.

Olguların patolojik evreleri ile reseptör ekspresyonlarının karşılaştırılmasında; patolojik evre arttıkça AR ekspresyonunun azaldığ görüldü. Patolojik evre ile AR ekspresyonu arasında da negatif korelasyon olduğu görüldü $(\mathrm{p}=0.026)$.

Tümör çapı ile AR ekspresyonu arasındaki ilişki istatistiksel olarak anlamlı bulunmadı ( $\mathrm{p}=0.06)$.

Olgularda AR ekspresyonu ile Ki-67 ekspresyonunun karşılaştırılmasında AR ile pozitif boyanan 14 olgudan 11 tanesinin Ki-67 indeksi, \%15'in üstündeydi. AR ile negatif boyanan 12 olgudan ise 5 tanesinin Ki-67 indeksi \%15'in üstündeydi. Ki-67 indeksi ve AR ekspresyonu arasında istatistiksel olarak anlamlı farklılık bulundu ( $\mathrm{p}=0.024)$.

AR ekspresyonu ile östrojen reseptörü $(p=0.031)$, progesteron reseptörü $(p=0.024)$ ve HER-2/neu ekspresyonu $(p=0.046)$ arasında istatistiksel olarak anlamlı bir ilişki mevcuttu. Androjen reseptörü ekspresyonu ve diğer parametreler arasındaki ilişki Tablo 1'de gösterilmiştir. 
Tablo 1. Androjen reseptörü ekspresyonu ve diğer parametreler arasındaki ilişki

\begin{tabular}{|c|c|c|c|c|c|c|c|}
\hline \multirow{2}{*}{ Değişken } & \multirow{2}{*}{ Kategori } & \multicolumn{2}{|c|}{ AR Pozitif } & \multicolumn{2}{|c|}{ AR Negatif } & \multirow{2}{*}{$X^{2}$} & \multirow{2}{*}{$\mathbf{P}$} \\
\hline & & $\mathbf{n}$ & $\%$ & $\mathbf{n}$ & $\%$ & & \\
\hline \multirow{2}{*}{ Tümör tipi } & $\begin{array}{ll}\text { İnvaziv } & \text { Duktal } \\
\text { Karsinom } & \\
\end{array}$ & 15 & 75,00 & 5 & 25,00 & \multirow{2}{*}{0,163} & \multirow{2}{*}{0,686} \\
\hline & Diğerleri & 4 & 66,67 & 2 & 33,33 & & \\
\hline \multirow{2}{*}{ Yaş } & Premenopozal & 4 & 33,33 & 8 & 66,67 & \multirow{2}{*}{1,474} & \multirow{2}{*}{0,225} \\
\hline & Postmenopozal & 8 & 57,14 & 6 & 42,86 & & \\
\hline \multirow{2}{*}{ Tümör çapı } & $<5 \mathrm{~cm}$ & 15 & 75,00 & 5 & 25,00 & \multirow{2}{*}{3,540} & \multirow{2}{*}{0,060} \\
\hline & $>5 \mathrm{~cm}$ & 2 & 33,33 & 4 & 66,67 & & \\
\hline \multirow{2}{*}{$\begin{array}{l}\text { Lenfovasküler } \\
\text { invazyon }\end{array}$} & Pozitif & 2 & 20,00 & 8 & 80,00 & \multirow{2}{*}{5,850} & \multirow{2}{*}{0,016} \\
\hline & Negatif & 11 & 68,75 & 5 & 31,25 & & \\
\hline \multirow{2}{*}{$\begin{array}{l}\text { Aksiller lenf nodu } \\
\text { tutulumu }\end{array}$} & Pozitif & 5 & 31,25 & 11 & 68,75 & \multirow{2}{*}{7,491} & \multirow{2}{*}{0,006} \\
\hline & Negatif & 8 & 80,00 & 2 & 20,00 & & \\
\hline \multirow{3}{*}{ Tümör derecesi } & 1 & 6 & 75,00 & 2 & 25,00 & \multirow{3}{*}{4,875} & \multirow{3}{*}{0,087} \\
\hline & 2 & 5 & 41,67 & 7 & 58,33 & & \\
\hline & 3 & 1 & 16,67 & 5 & 83,33 & & \\
\hline \multirow{4}{*}{ Patolojik evre } & 1 & 4 & 60,00 & 1 & 40,00 & \multirow{4}{*}{$-9,276$} & \multirow{4}{*}{0,026} \\
\hline & 2 & 9 & 25,00 & 3 & 75,00 & & \\
\hline & 3 & 1 & 85,71 & 6 & 14,29 & & \\
\hline & 4 & 0 & 0,00 & 2 & 100,00 & & \\
\hline \multirow{2}{*}{ Kİ-67 } & $\leq 15$ & 3 & 30,00 & 7 & 70,00 & \multirow{2}{*}{5,106} & \multirow{2}{*}{0,024} \\
\hline & $>15$ & 12 & 70,59 & 5 & 29,41 & & \\
\hline \multirow{2}{*}{ Östrojen reseptörü } & Pozitif & 13 & 76,47 & 4 & 23,53 & \multirow{2}{*}{4,627} & 0031 \\
\hline & Negatif & 3 & 33,33 & 6 & 66,67 & & 0,031 \\
\hline Progesteron & Pozitif & 12 & 80,00 & 3 & 20,00 & 5106 & 0024 \\
\hline reseptörü & Negatif & 4 & 36,36 & 7 & 63,64 & $\sqrt{3,100}$ & 0,024 \\
\hline Her2-neu & Pozitif & 9 & 75,00 & 3 & 25,00 & 4013 & 0046 \\
\hline nerz-neu & Negatif & 5 & 35,71 & 9 & 64,29 & 4,015 & 0,040 \\
\hline
\end{tabular}

\section{TARTIŞMA}

Meme kanseri kadınlarda en sık görülen kanser türüdür ve kadınlardaki mortalitenin en yaygın ikinci sebebidir. Son 20 yılda, meme kanseri insidansında artış ancak mortalitesinde düşüş vardır (15).

Hastalar arasında tedaviye cevap, rekürrensler, tümör davranışı ve genel prognoz açısından önemli farklılıklar olduğu gözlenmektedir. Bu durum prognozu etkileyen başka faktörlerin bulunduğu düşüncesini ortaya çıkarmaktadır (16).

Meme kanserinde klinik gidişatı öngörmede östrojen reseptörü, progesteron reseptörü ve HER-2/neu durumunun belirlenmesi gerekmektedir (17). Bu spesifik moleküler belirteçlerin terapötik, prediktif ve prognostik önemleri kanıtlanmıştır (18). AR, sıklıkla ER, PR ve/veya HER2 reseptörü ile birlikte eksprese edilmekle birlikte tüm meme kanseri tiplerinde en sık eksprese edilen (\%47-\%90) seks steroid reseptörüdür (19).

Androjen reseptörünün meme kanserinde etkisi hakkında henüz bir fikir birliği yoktur ve çelişkili sonuçlar bildirilmiştir. Androjen reseptörünün meme kanserindeki rolü ihmal edilmiş olsa da, bir çalışma androjen reseptörü ile tümör biyolojisini ve gelişimini etkileyen diğer faktörler arasındaki ilişki konusunun multidisipliner bir yaklaşım kullanılarak değerlendirilmesi gerektiğini kaydetmiştir (20). Androjen reseptörü pozitifliği genellikle progesteron reseptörü negatif meme kanseri hastalarında bulunur; bu nedenle androjen reseptörü sinyal yolunun meme kanseri karsinogenezinde önemli ve kritik bir rolü olduğu düşünülmektedir (21). Önceki çalışmalar, androjen reseptörü pozitifliğinin östrojen

277 | P a g e www.iiste.org 
reseptörü pozitif meme kanseri hastalarında östrojen reseptörü negatif meme kanseri hastalarına göre daha yüksek olduğunu bildirmiştir $(22,23)$. Androjen reseptörü pozitifliği daha önce östrojen reseptörü ve progesteron negatif olan meme kanseri hastalarının\% 9-56'sında da tanımlanmıştır (24, 25). Çalışmamızda, androjen reseptörü pozitif olan hastaların \% 76.4'ünde östrojen reseptörü pozitif, androjen reseptörü pozitif olan hastaların \% 66.6'sinde progesteron reseptör pozitifliği saptanmıştır.

Androjen reseptörü ve östrojen reseptörü pozitifliği ile androjen reseptörü ve progesteron reseptörü pozitifliği arasında istatistiksel olarak anlamlı ilişkiler vardı. HER-2/neu amplifikasyonu ve overekspresyonu meme kanserinde \% 25-30 oranında görülür (26). HER-2/neu aşırı ekspresyonu, invaziv duktal karsinomların \%20-30’unda bulunmaktadır (27).

$\mathrm{Yu}$ ve ark. androjen reseptörü pozitif meme kanseri hastalarının \% 65.9'unda HER-2/neu pozitifliğinin görüldüğünü saptanmıştır (28). Başka bir çalışmada 599 androjen reseptörü pozitif meme kanseri hastası değerlendirilmiş ve \% 12'sinde HER-2/neu pozitifliği saptanmıştır (29). Bizim çalışmamızda, androjen reseptörü pozitif meme kanseri hastalarının\% 50'sinde HER-2/neu pozitifliği tespit edilmiştir.

Gonzalez-Angulo ve ark. 347 primer meme kanseri üzerinde yaptıkları çalışmada ER ve/veya PR pozitif kanserlerin en yüksek AR ekspresyonuna sahip olduğunu triple negatif tümörlerin ise en düşük $\mathrm{AR}$ düzeyine sahip olduğunu belirtmişlerdir (30). Luo ve ark.'nın yaptığı çalışmada AR, 137 triple negatif olgunun 38'inde $(\% 27,7)$, triple negatif olmayan 132 olgunun 110 'unda $(\% 83,3)$ eksprese olmuştur ve gruplar arası fark anlamlı bulunmuştur (31). Ogawa ve ark. meme kanserlerinin \% 18,5'inin triple negatif meme kanseri olduğunu ve triple negatif tümörlerin \%43'ünün AR pozitif olduğunu bildirmişlerdir (32). Niemeier ve ark. çalışmalarında triple negatif olgularının sadece \%10'unda (3/30) androjen reseptör ekspresyonu bulurken (33), Collins ve ark. 2171 invaziv kanserden oluşan serilerinde triple negatif olgularda AR ekspresyonunu \%32 (75/237) oranında bulmuşlardır (34).

Yaptığımız çalışmada, postmenopozal hasta sayısı daha fazla idi. Menopozal durum ile AR arasında istatistiksel olarak anlamlı bir ilişki bulunmasa da Luo ve Agoff'un $(31,35)$ yaptığ çalışmaya benzer olarak postmenopozal grupta premenopozal gruba göre daha fazla AR ekspresyonu tespit edilmiştir.

Collins ve ark.'nın çalışmasında AR negatif tümörlere göre AR pozitif tümörler daha az sayıda idi ve çoğunlukla lenf nodu negatif, daha düşük dereceli ve evresi daha düşük tümörlerdi (34). Çalışmada AR ekspresyonunun küçük tümör boyutu, lenf nodu metastazının olmaması, düşük histolojik derece ve ER ekspresyonu gibi pozitif prognostik faktörlerle ilişskili olduğu ve meme kanserinde prognostik ve prediktif bir faktör olduğu bildirilmiştir $(32,34,36)$.

Bizim çalışmamızda vakaların 8'i derece 1, 12'si derece 2, 6's1 ise derece 3 ile uyumluydu. Tümör dereceleri ile AR ekspresyon durumu karşılaştırıldığında derece 1 ile uyumlu olan 8 olgunun 6 tanesinde (\%75.0) AR pozitif, derece 2 ile uyumlu 12 olgunun ise 5 tanesinde (\%41.6) AR pozitif, derece 3 ile uyumlu 6 olgunun 1 tanesinde (\%16.6) AR pozitif bulundu. Bu sonuca göre bulgular, literatürün aksine AR ekspresyonunun ile derece arasındaki ilişki istatistiksel olarak da anlamlı bulunmadı ( $\mathrm{p}=0.087)$.

Ki-67, hücre çoğalması için bir belirteç olan bir nükleer antijendir. Pistelli ve ark, AR pozitifliği ile Ki67 yüksekliği ve lenfovaskuler invazyon arasında negatif korelasyon bulmuşlardır (37). Mrlic ve ark. Ki67 indeksi ile AR pozitifliği arasındaki ters ilişkiyi göstererek AR'nin antiproliferatif etkilerinin olduğunu savunmuşlardır (38).

Sutton ve ark. AR pozitif grupta Ki-67 indeksi ile anlamlı negatif korelasyon olduğunu belirtmişlerdir. (39).

Çalışmamızda Ki-67 İndeksi, androjen reseptörü (+) meme kanseri hastalarının \% 26.6'sında \% 15 altında, androjen reseptörü (+) meme kanseri hastalarının\% 73.3'ünde \%15'in üstündedir.

Çalışmamızda, androjen reseptörü $(+)$ meme kanseri hastalarının \% 11.5 'inde triple negatif hormon profili bulunmuştur.

Androjen reseptörleri meme, kemik ve beyin gibi hemen her dokuda bulunmaktadır ve metabolitleri ile birlikte normal doku homeostazını sağlamada önemli role sahiptirler. Ayrıca AR normal meme epitelinde ve kanserli dokuların büyük çoğunluğunda eksprese edilmektedir (40). Androjen sinyal yolunun, normal ve malign meme dokusunda önemli rol oynadığını ortaya koyan kanıtlar mevcuttur (41).

Yüksek AR ekspresyon seviyeleri tanı anında ileri yaşta olma, tümörde yüksek ER ve/veya PR ekspresyonu, düşük nükleer derece ve küçük tümör boyutu gibi iyi prognostik kriterler ile ilişkilendirilmiş ve düşük malignite potansiyelinin göstergesi olarak kabul edilmiştir $(39,40)$. Düşük AR ekspresyonu ise erken dönem metastaz, kısa hastalıksız ara dönem ve düşük sağkalım oranı ile ilişkilendirilmiştir (42). Androjen reseptörü ekspresyonunun östrojen reseptörü ekspresyonu ile iyi korele olduğu; bu nedenle androjen reseptörü ekspresyon durumu, hormonal tedaviye yanıt verme olasılığı en yüksek olan meme kanseri hastalarını daha doğru bir şekilde tanımlayabilir. Bu sonuçlar meme kanseri hastalarında androjen reseptörlerinin etkisinin hem tek başına hem de diğer reseptörlerle birlikte değerlendirilmesi gerektiğini göstermektedir (43). 
Sonuç olarak androjen reseptörü pozitifliği daha iyi klinik sonuçlarla ilişkilidir (düşük dereceli, düşük lenfovasküler invazyon, düşük aksiller lenf nodu tutulumu ). Hem östrojen reseptörü hem de progesteron reseptörü pozitifliği ile korelasyonu, bu reseptörün prediktif ve prognostik değerinin hastanın östrojen reseptörü ve progesteron reseptörlerinin durumu değerlendirilerek arttırılabileceğini düşündürmektedir. Bu korelasyonu ve androjen reseptörünün klinik sonuç üzerindeki etkisini ortaya koymak için büyük multidisipliner çalışmalara ihtiyaç duyulacaktır.

\section{REFERANSLAR}

1. Montazeri A, Vahdaninia M, Harirchi I, Harirchi AM, Sajadian A, Khaleghi F, et al. Breast cancer in Iran: need for greater women awareness of warning signs and effective screening methods. Asia Pac Fam Med 2008;7:6.

2. Evcimik, T. Meme kanserinde prognostik faktörlerin sağ kalıma etkisi. [Uzmanlık Tezi], İstanbul: T.C Sağlık Bakanlığı İstanbul Göztepe Eğitim ve Araştırma Hastanesi; 2008.

3. Colleoni M, Viale G, Zahrieh D, Pruneri G, Gentilini O, Veronesi P, Gelber RD, Curigliano G, Torrisi R, Luini A, Intra M, Galimberti V, Renne G, Nole F, Peruzzotti G, Goldhirsch A. Chemotherapy is more effective in patients with breast cancer not expressing steroid hormone receptors: a study of preoperative treatment. Clin Cancer Res 2004; 10: 6622-6628.

4.Wang W, John EM, Ingles SA. Androgen receptor and prostate-specific antigen gene polymorphisms and breast cancer in African-American women. Cancer Epidemiol Biomarkers Prev. 2005;14: 2990-2994.

5. Kuenen-Boumeester V, Van der Kwast TH, van Putten WL. Claassen C, van Ooijen B, HenzenLogmans SC. Immunohistochemical determination of androgen receptors in relation to estrogen and progesterone receptors in female breast cancer. Int J Cancer. 1992;52: 581-584

6. Agrawal AK, Grzebieniak Zukrowski P. An analysis of the correlations between the presence of androgen receptors and other prognostic factors in women with breast cancer. Nowotwory. 2007;4: 383-390.

7. Ni M, Chen Y, Lim E, Wimberly H, Bailey ST, Imai Y et al: Targeting androgen receptor in estrogen receptor-negative breast cancer. Cancer Cell 2011, 20: 119-131.

8. Agoff SN, Swanson PE, Linden H, Hawes SE, Lawton TJ: Androgen receptor expression in estrogen receptor-negative breast cancer. Immunohistochemical, clinical, and prognostic associations. Am J Clin Pathol 2003, 120(5):725-731.

9. Gonzalez-Angulo AM, Stemke-Hale K, Palla SL, Carey M, Agarwal R, Meric- Berstam F. et al: Androgen receptor levels and association with PIK3CA mutations and prognosis in breast cancer. Clin Cancer Res 2009, 15(7):2472-2478.

10. Peters KM, Edwards SL, Nair SS, French JD, Bailey PJ, Salkield K et al: Androgen receptor expression predicts breast cancer survival: the role of genetic and epigenetic events. Cancer 2012, 12:132

11. Hu R, Dawood S, Holmes MD, Collins LC, Schnitt SJ, Cole K et al. Androgen receptor expression and breast cancer survival in postmenopausal women. Clin Cancer Res 2011;17(7):1867-74.

12. Schippinger W, Regitnig P, Dandachi N, Wernecke KD, Bauernhofer T, Samonigg H et al. Evaluation of the prognostic significance of androgen receptor expression in metastatic breast cancer. Virchows Arch 2006;449(1):24-30.

13. Niemeier LA, Dabbs DJ, Beriwal S, Striebel JM, Bhargava R. Androgen receptor in breast cancer: expression in estrogen receptor-positive tumours and in estrogen receptor-negative tumours with apocrine differentiation. Mod Pathol Off J U S Can Acad Pathol Inc 2010; 23: 205-212. 
14. Qi JP, Yang YL, Zhu H, Wang J, Jia Y, Liu N, Song YJ, Zan LK, Zhang X, Zhou M, Gu YH, Liu T, Hicks DG, Tang P. Expression of the androgen receptor and its correlation with molecular subtypes in 980 Chinese breast cancer patients. Breast Canc Basic Clin Res 2012; 6: 1-8.

15. Bombonati A, Sgroi DC. The molecular pathology of breast cancer progression. J Pathol, 2011; 223: $307-317$

16. Alizadeh AA, Ross DT, Perou CM, van de Rijn M. Towards a novel classification of human malignancies based on gene expression patterns. J Pathol, 2001; 195:41-52.

17. Cetin I, Topcul M. Triple Negative Breast Cancer. Asian Pac J Cancer Prev, 2014; 15: 2427-2431.

18. Choccalingam C, Rao L, Rao S. Clinico-Pathological Characteristics of Triple Negative and Non Triple Negative High Grade Breast Carcinomas with and Without Basal Marker (CK5/6 and EGFR) Expression at a Rural Tertiary Hospital in India. Breast Cancer: Basic and Clinical Research, 2012; 6: 21-29.

19. Safarpour D, Tavassoli FA. A Targetable Androgen Receptor-Positive Breast Cancer Subtype Hidden Among the Triple-Negative Cancers. Arch Pathol Lab Med, 2014; 139: 612-617.

20. Moe RE, Anderson BO. Androgens and androgen receptors: a clinically neglected sector in breast cancer biology. J Surg Oncol 2007; 95: 437-439.

21. Yu Q, Niu Y, Liu N, Zhang JZ, Liu TJ. Expression of androgen receptor in breast cancer and its significance as a prognostic factor. Ann Oncol 2011; 22: 1288-1294.

22. Schippinger W, Regitnig P, Dandachi N, Wernecke KD, Bauernhofer T. Evaluation of the prognostic significance of androgen receptor expression in metastatic breast cancer. Virchows Arch 2006; 449: 24-30.

23. Peters AA, Buchanan G, Ricciardelli C, Bianco-Miotto T, Centenera MM, Harris JM, Jindal S, Segara D, Jia L, Moore NL, Henshall SM, Birrell SN, Coetzee GA, Sutherland RL, Butler LM, Tilley WD. Androgen receptor inhibits estrogen receptor alfa activity and is prognostic role in breast cancer. Cancer Res 2009; 69: 6131-6140.

24. Rakha EA, El-Sayed ME, Green AR, Paish EC, Lee AH, Ellis IO. Breast carcinoma with basal differentiation: a proposal for pathology definition based on basal cytokeratin expression. Histopathol 2007; 50: 434-438.

25. Park S, Koo J, Park HS, Kim JH, Choi SY. Expression of androgen receptors in primary breast cancer. Ann Oncol 2010; 21: 488-492.

26. Hanna W. Testing for HER2 status. Oncology. 2001; 61: 22-30.

27. Rosai J. Rosai and Ackerman's Surgical Pathology, Mosby 2011, tenth edition, volume two, 16601733.

28. Yu Q, Niu Y, Liu N, Zhang JZ, Liu TJ. Expression of androgen receptor in breast cancer and its significance as a prognostic factor. Ann Oncol 2011; 22: 1288-1294.

29. Castellano I, Allia E, Accortanzo V, Vandone AM, Chiusa L, Arisio R, Durando A, Donadio M, Bussolati G, Coates AS, Viale G, Sapino A. Androgen receptor expression is a significant prognostic factor in estrogen receptor positive breast cancers. Breast Cancer Res Treat. 2010: 124: 607-617. 
30. Gonzalez-Angulo AM, Stemke-Hale K, Palla SL, Carey M, Agarwal R, Meric- Berstam F et al. Androgen receptor levels and association with PIK3CA mutations and prognosis in breast cancer. Clin Cancer Res, 2009; 15(7):2472-2478.

31. Luo X, Shi YX, Li ZM, Jiang W. Expression and clinical significance of androgen receptor in triple negative breast cancer. Chin J Cancer, 2010; 29; 6:585-90.

32. Ogawa Y, Hai E, Matsumoto K, Ikeda K, Tokunaga S, Nagahara H et al. Androgen receptor expression in breast cancer: relationship with clinicopathological factors and biomarkers. Int $\mathrm{J}$ Clin Oncol, 2008; 13(5):431-5.

33. Niemeier LA, Dabbs DJ, Beriwal S, Striebel JM, Bhargava R. Androgen receptor in breast cancer: expression in estrogen receptor-positive tumors and in estrogen receptornegative tumors with apocrine differentiation. Mod Pathol, 2010; 23:205-212.

34. Collins LC, Cole KS, Marotti JD, Hu R, Schnitt SJ, Tamimi RM. Androgen receptor expression in breast cancer in relation to molecular phenotype: results from the Nurses' Health Study. Mod Pathol, 2011; 24: 924-31.

35. Agoff SN, Swanson PE, Linden H, Hawes SE, Lawton TJ. Androgen receptor expression in estrogen receptor-negative breast cancer. Immunohistochemical, clinical, and prognostic associations. Am J Clin Pathol, 2003; 120(5):725-31.

36. Rakha EA, El-Sayed ME, Green AR, Lee AHS, Robertson JF, Ellis IO. Prognostic markers in triple negative breast cancer. Cancer, 2007; 109:25-32.

37. Pistelli M, Caramanti M, Biscotti T, Santinelli A, Pagliacci A, De Lisa M, Ballatore Z, Ridolfi F, Maccaroni E, Bracci R, Berardi R, Battelli N, Cascinu S. Androgen Receptor Expression in Early Triple-Negative Breast Cancer: Clinical Significance and Prognostic Associations. Cancers, 2014; 6: 1351-1362.

38. Mrklić I, Pogorelić Z, Capkun V, Tomić S. Expression of androgen receptors in triple negative breast carcinomas. Acta Histochem, 2013; 115: 344-8.

39. Sutton LM, Cao D, Sarode V, Molberg KH, Torgbe K, Haley B, Peng Y. Decreased Androgen Receptor Expression Is Associated With Distant Metastases in Patients With Androgen ReceptorExpressing Triple-Negative Breast Carcinoma. Am J Clin Pathol, 2012; 138: 511-516.

40. Dimitrakakis C, Bondy C. Androgens and the breast. Breast Cancer Res, 2009; 11: 212-221.

41. Tokunaga E, Hisamatsu Y, Taketani K, Yamashita N, Akiyoshi S, Okada S, Tanaka K, Saeki H, Oki E, Aishima S, Oda Y, Morita M, Maehara Y. Differential impact of the expression of the androgen receptor by age in estrogen receptor-positive breast cancer. Cancer Med, 2013; 2: 763773.

42. Safarpour D, Pakneshan S, Tavassoli FA. Androgen receptor (AR) expression in 400 breast carcinomas: is routine AR assessment justified. Am J Cancer Res, 2014; 4: 353368.

43. Mishra AK, Agrawal U, Negi S, Bansal A, Mohil R. Expression of androgen receptor in breast cancer \& its correlation with other steroid receptors \& growth factors. Indian J Med Res 2012; 135: 843-852. 